\title{
CRÍTICAS À EMENDATIO LIBELLI E O ENFRAQUECIMENTO DO DEVIDO PROCESSO LEGAL
}

\section{CRITICISM OF EMENDATIO LIBELLI AND THE WEAKENING OF DUE PROCESS OF LAW}

\author{
Lucas Ruas Drummond*
}

\begin{abstract}
RESUMO
Expresso no Título XII (Da sentença) do vigente Código de Processo Penal, mais precisamente no artigo 383, a figura da emendatio libelli permite ao Magistrado atribuir definição jurídica diversa ao caso penal, desde que não altere a narração fática, mesmo que em consequência, aplique pena mais grave. Após a reforma de 2008, pequenas alterações foram promovidas, mantendo, porém, a essência do instituto. Nesse norte, o presente trabalho busca, através de uma sistemática dialética, apresentar críticas à figura e discutir sobre suas particularidades e efeitos no processo penal, considerando uma eventual incompatibilidade e essencial reinterpretação, tendo como referencial uma necessária filtragem constitucional do processo penal brasileiro que ainda demonstra traços inquisitórios. Assim, valendo-se de uma pesquisa bibliográfica sobre o tema, objetiva-se problematizar a questão da emendatio libelli e ponderar a respeito de seus reflexos negativos no devido processo legal. Ainda, as alterações promovidas pela Lei 13.964/19, denominado de "Pacote Anti Crime", que expressamente consagrou o sistema acusatório e inovou outros procedimentos regulados no Código de Processo Penal, também primando por uma adequação acusatória do processo penal, ensejam a presente (re)discussão para que seja repensado o procedimento criminal com os ares democráticos e garantistas que devem ser aspirados por todos os atores judiciários.
\end{abstract}

Palavras chave: Emendatio libelli. Devido processo legal. Sentença. Processo Penal

\begin{abstract}
Expressed in Title XII (Sentencing) of the current Code of Criminal Procedure, more precisely in the article 383, the figure of emendatio libelli allows the Magistrate to assign a different legal definition to the criminal case, since the factual narration remains equal, even if as a consequence, apply more severe penalty. After the 2008 reform, minor changes were made, keeping, however, the essence of the institute. In this direction, the present work seeks, through a dialectical systematic, to criticize the figure and discuss it's particularities and effects on the criminal procedure, considering a possible incompatibility and essential reinterpretation, having as a reference a necessary constitutional filtering of the brazilian criminal procedure that still shows inquisitorial traits. Thus, using a bibliographic research on the subject, the objective is to problematize the issue of the emendatio libelli and to consider it's negative consequences in the due process of law. Also, the changes promoted by law 13.964/19, called "Anti Crime Package", which expressly established the accusatorial system and innovated other procedures regulated in the code of criminal procedure, also striving for an accusatory suitability of the criminal procedure,
\end{abstract}

Artigo submetido em 14 de outubro de 2021 e aprovado em 07 de fevereiro de 2022

*Bacharel em Direito pela Pontifícia Universidade Católica de Minas Gerais, campus Coração Eucarístico E-mail: lucasdrummond23@hotmail.com 
give rise to the present (re)discussion so that the criminal procedure can be reconsidered with the democratic and guaranteeing airs that must be aspired by all judicial actors.

Keywords: Emendatio libelli. Due process of law. Sentence. Criminal Procedure

\section{INTRODUÇÃO}

O presente trabalho buscou analisar o artigo 383 do Código de Processo Penal (CPP) que dispõe a respeito da figura da emendatio libelli, mediante uma visão constitucionalizada do processo, de maneira dialética, suscitando eventuais problemas oriundos de sua aplicação acrítica que podem impactar a garantia do devido processo legal, mirando a mudança de postura quanto a interpretação e aplicação do instituto. Para tanto, foi utilizada uma abordagem de pesquisa e exposição de entendimentos doutrinários, explorando-os e comentando-os, tendo sempre como parâmetro os direitos e garantias da Constituição da República Federativa do Brasil (CRFB). O presente trabalho foi dividido em cinco tópicos, de forma a introduzir os elementos indispensáveis à compreensão da problemática, seguido da crítica objeto do trabalho e posterior conclusão e sugestão, a começar pela presente introdução sobre a temática.

O segundo tópico se propôs a conceituar e expor algumas categorias jurídicas próprias do direito processual penal, que posteriormente foram adotadas e esmiuçadas ao longo do trabalho, na função de se compreender premissas básicas que permitam a crítica e debate mais aprofundado do objeto do presente artigo, qual seja, a emendatio libelli. O terceiro tópico se prestou, igualmente, a expor princípios jurídicos aplicáveis à figura do artigo 383 do CPP, complementando as deliberações feitas no segundo capítulo e analisando as normas jurídicas, bem como a adequação da emendatio libelli para com os princípios expostos. O quarto capítulo tratou da emendatio libelli e os efeitos de seu emprego na sentença, levando em conta as deliberações anteriores, sendo o cerne do trabalho a análise de tal momento procedimental. Por fim, o tópico quinto traz as conclusões e ponderações finais, bem como uma sugestão prática de como compatibilizar a figura tratada com o devido processo constitucional.

A premissa de que o instituto da emendatio libelli é adequado e pode ser aplicado sem maiores problemas deve ser repensada. A figura resta assentada nos brocardos iura novit curia e naha mihi factum, dabo tibi ius, que significam, respectivamente, que "O juízo conhece a lei" e "Dá-me os fatos que lhe darei o direito". Uma análise superficial dos elementos não levanta maiores indagações, porém, longe de se defender o pleno equívoco dos brocardos, maiores atenções devem ser dispostas sobre o que pretendem justificar. A permissão para que o Magistrado, na sentença, atribua capitulação jurídica diversa, mantendo hígida a narração fática, podendo, inclusive punir o acusado de forma mais gravosa, levanta sérios questionamentos sobre a constitucionalidade da permissão. Em todas as áreas jurídicas, a prevalência do texto constitucional é tema incontroverso, haja vista tratar-se de texto legal de maior hierarquia no ordenamento jurídico, devendo a interpretação e aplicação normativa observar, inicialmente, as diretrizes constitucionais.

A sentença é a manifestação derradeira e exauriente no juízo de primeiro grau, que analisa ou não a questão de mérito (definitiva ou terminativa) posta à sua apreciação, conforme os artigos 485 e 487 do Código de Processo Civil (CPC). Tendo como objetivo procedimental derradeiro tal manifestação judicial, para que, após a instrução, o Magistrado forme sua convicção e preste a tutela jurisdicional às partes, a legalidade e validade do título executivo judicial depende integralmente da participação substancial das partes envolvidas (contraditório) na defesa de seus interesses (ampla defesa). Em outras palavras, toda a prestação jurisdicional possui condições de legitimidade a serem observadas durante todo o trâmite procedimental, e a inobservância de uma oportunidade das partes se manifestarem sobre circunstância aplicável 
na sentença, que, diga-se de passagem, pode não ter sido objeto de debate (contraditório) durante o processo, torna o pronunciamento jurisdicional nulo em face de violação a direitos e garantias de magnitude constitucional como a ampla defesa e o contraditório, vigas mestras do devido processo legal, previstos no artigo $5^{\circ}$ LIV e LV da CRFB (BRASIL, 1988).

Nesse norte, indaga-se se a disposição do artigo 383 se adequa a uma leitura constitucional do processo e seus pressupostos de validade, notadamente em se tratar de um dispositivo do processo penal, ramo legal responsável pela liberdade dos sujeitos, bem jurídico de importância imensurável, assegurado no caput do artigo $5^{\circ}$ da CRFB (BRASIL, 1988), inaugurando o título "Dos direitos e garantias fundamentais". Assim, o presente trabalho buscará discorrer sobre a conformidade da emendatio libelli ao processo penal brasileiro, primando pela máxima asseguração de direitos e garantias individuais, funcionando o direito processual penal como verdadeiro instrumento de contenção do poder punitivo estatal na busca constante de um aprimoramento das ciências jurídicas e da concretização do princípio da dignidade da pessoa humana assegurado no artigo $1^{\circ}$, III da CRFB (BRASIL, 1988).

\section{BASES DO PROCESSO PENAL}

Não são poucas as teorias que buscam conceituar a fenomenologia do direito processual. Algumas se opõem, outras se agregam, de modo que se torna extremamente complexo adotar apenas uma teoria: Teoria do processo como relação jurídica (BULOW, 1868); Teoria do processo como procedimento em contraditório (FAZZALARI, 1978); Teoria do processo como instituição (GUASP, 1968); Teoria Constitucionalista do processo (FIX-ZAMUDIO, 1956); Teoria do processo como situação jurídica (GOLDSCHMIDT, 1925), dentre várias outras. Porém, na esteira de Aury Lopes Jr., esta última, do processo como situação jurídica, é a que mais se adequa ao direito processual penal.

Entende GOLDSCHMIDT que o processo é um conjunto de situações processuais pelas quais as partes atravessam, em direção a uma sentença definitiva favorável. Ressalta o autor que o processo é uma situação de riscos, chances, incertezas, complexidades e cargas, negando a existência de uma distribuição das cargas probatórias (natural do processo civil), mas sim uma atribuição de carga, no caso, ao acusador, vez que o acusado é escudado pelo manto da presunção de inocência, previsto no artigo $5^{\circ}$, LVII da CRFB (BRASIL, 1988). Portanto, cabe ao acusado, assistido por sua defesa, se defender nos moldes daquilo que lhe foi imputado pelo acusador, estando integralmente condicionado à pretensão acusatória exercida.

Nesse raciocínio, o não aproveitamento de uma chance para se desincumbir da carga probatória, aumenta a expectativa de uma sentença desfavorável. E assim, as partes se direcionam à prolação de uma decisão, que será construída em face de suas posturas durante o procedimento, porém, sempre incerta e imprevisível.

O sistema acusatório vinha implicitamente adotado na Constituição Federal, ao atribuir ao Ministério Público a titularidade da ação penal pública, segundo o artigo 129, I da CRFB (BRASIL, 1988), tendo sido expressamente adotado no artigo $3^{\circ}$-A do Código de Processo Penal, com o advento da Lei 13.964/19, a despeito da suspensão liminar do dispositivo por tempo indeterminado pelo Supremo Tribunal Federal.

O sistema acusatório se caracteriza pela distinção entre acusar e julgar, iniciativa probatória das partes, imparcialidade judicial, paridade de armas, garantia do contraditório e da ampla defesa, dentre outros traços, afetos a um Estado Democrático de Direito. Noutro giro, o sistema inquisitório, típico de Estados autoritários, se caracteriza pela aglutinação das funções de acusar e julgar na mesma figura, parcialidade do juiz (e não poderia ser diferente, pois como afastar/desqualificar uma tese desenvolvida pela própria pessoa que a está julgando?), sigilo e contraditório, simbólico, quando muito. 
O principal aspecto que interessa o presente trabalho circula em torno do princípio dispositivo (ou acusatório), assegurando a inércia jurisdicional, que será devidamente provocada pelas partes envolvidas. A rígida separação das atividades é a única forma de se garantir a imparcialidade do juiz, e a prestação jurisdicional adequada.

O objeto do processo penal, partindo de suas categorias próprias, é dada por AURY LOPES JR., quando leciona:

\begin{abstract}
Concluindo, o objeto do processo penal é uma pretensão acusatória, vista como a faculdade de solicitar a tutela jurisdicional, afirmando a existência de um delito, para ver ao final concretizado o poder punitivo estatal pelo juiz através de uma pena ou medida de segurança. O titular da pretensão acusatória será o Ministério Público ou o particular. Ao acusador (público ou privado) corresponde apenas o poder de invocação (acusação), pois o Estado é o titular soberano do poder de punir, que será exercido no processo penal através do juiz, e não do Ministério Público (e muito menos do acusador privado. (LOPES JR., 2021, p. 57)
\end{abstract}

O objeto do processo penal, conceito de fundamental importância para que se delimite adequadamente o campo discursivo-decisório do caso posto à apreciação judicial, pode ser destrinchado em três elementos fundantes. O elemento subjetivo refere-se aos sujeitos envolvidos na relação jurídico-processual composta pela figura acusatória (Ministério Público ou particular) que exerce a pretensão de acusar, o imputado, contra quem é deduzida a pretensão em juízo, e, por fim, o órgão julgador, representado pelo Estado-Juiz. Observa-se por esta sistemática a tríplice identidade de sujeitos (actum trium personarum), com as funções de acusar, defender e julgar devidamente individualizadas. Cabe salientar que a pretensão acusatória pertence ao acusador, e a pretensão punitiva pertence ao Estado-Juiz.

O segundo elemento da pretensão processual penal é o objetivo, que trata do conteúdo desta pretensão, ou seja, o fato típico, ilícito e culpável, de acordo a teoria tripartite do crime adotada pela legislação pátria. Importante apontar que o caso penal não é o objeto do processo penal, senão um de seus componentes. Por fim, o último elemento é a declaração petitória, ou seja, o pedido postulado pelo acusador perante o julgador, apresenta-se como o pleito de que se reconheça o cometimento pelo imputado de um fato típico, ilícito e culpável, declarando a infringência à norma penal, impondo-lhe a sanção cominada ao tipo penal violado. Portanto, percebemos três poderes-deveres distintos incidentes na relação processual, quais sejam, o de acusar defender e de julgar, imiscíveis entre si e devidamente delineados e limitados, assegurando a imparcialidade, legalidade e a dialeticidade, única forma legítima de eventual sancionamento criminal.

A exposição destas premissas básicas, mesmo que brevemente, é importante, na medida que serão reaproveitadas quando da discussão da emendatio libelli e seus consectários.

\title{
3 PRINCIPIOLOGIA CORRELATA
}

Associando-se às categorias básicas do direito processual penal, é importante que se delibere a respeito da principiologia incidente no objeto do presente trabalho, reforçando o ponto de vista defendido e estimulando a postura crítica perante a emendatio libelli. A principiologia de qualquer área é de determinante relevância para que se ofereça um sustentáculo firme no desenvolvimento e aprimoramento de um determinado tópico. Em outras palavras, princípios são idéias básicas e fundamentais que dão suporte às ciências.

Tomando-se por base esta concepção tradicional, pode-se dizer que os princípios jurídicos se caracterizam como diretrizes gerais induzidas e indutoras do direito, porque são inferidas de um sistema jurídico e, após inferidas, se reportam ao próprio 
sistema jurídico para informá-lo, como se fossem alicerces de sua estrutura. (BRÊTAS, 2018, p. 145)

Dentre as principais funções exercidas pelos princípios, podem ser apontadas as seguintes: Função interpretativa (Permitir e auxiliar a segura revelação e compreensão do direito); Função supletiva (Fonte normativa subsidiária, em situações de lacuna e omissão na regra de direito); Função normativa própria (Constituem verdadeiras normas jurídicas autônomas). Seguindo a trilha do que exposto sobre o sistema acusatório, importante frisar ainda que sua congruência à democracia é mais um dos motivos para crer que temos um processo penal acusatório. A valorização do homem e da dignidade humana constituem fundamentos e objetivos da República Federativa do Brasil, incumbindo ao Estado assegurar essa valorização também no âmbito criminal.

Por isso o investigado, que no sistema inquisitório era tratado como objeto de persecução, no acusatório é tido como sujeito de direitos, que apenas pode ser legitimamente apenado após o transcurso do devido processo penal, banhado pelos direitos e garantias individuais. O plano democrático se amolda integralmente ao princípio acusatório: Titularidade da ação penal pública pelo Ministério Público; Contraditório e ampla defesa; Devido processo legal; Presunção de inocência e exigência de publicidade e fundamentação das decisões judiciais, previstos, respectivamente, nos artigos 129, I; $5^{\circ}$ LV, LIV, LVII e 93, IX, todos da CRFB (BRASIL, 1988).

O contraditório é sinônimo de participação. Tal garantia é assegurada no artigo $5^{\circ}, \mathrm{LV}$ da CRFB (BRASIL, 1988), no artigo $8^{\circ}$, itens 1 e 2 da Convenção Americana de Direitos Humanos, bem como artigo 14 do Pacto Internacional sobre Direitos Civis e Políticos, ambos tratados internacionais de direitos humanos internalizados pelo Brasil. A participação a ser franqueada aos litigantes é cumprimento da disposição constitucional, voltado à legitimação do exercício do poder pelo Estado, vez que absolutamente reprovável sofrer um gravame do qual não lhe foi possibilitado influir de forma substancial.

As partes, conhecedoras iniciais dos fatos discutidos, são aqueles que mais adequadamente devem praticar atos na defesa do seu interesse, arrolando testemunhas, produzindo provas, apresentando documentos e assim por diante. E nesta linha, o Juiz, terceiro espectador, alheio ao caso, recebe a provocação das partes para que forme seu livre convencimento motivado e preste a tutela jurisdicional. E cabe ao Magistrado ser ativo nesse quesito (não se confunde com uma postura inquisitória), possibilitando a manifestação das partes, prezando pelo regular curso do processo, e, principalmente, dialogando com as partes para que se atinja, preferencialmente, uma decisão de mérito.

A maioria da doutrina entende que o contraditório pode ser destrinchado em dois momentos, quais sejam, a informação e a reação. Entretanto (BRÊTAS, 2018) adota uma visão quadripartite do contraditório, composto por informação, reação, diálogo e influência. A informação é a primeira etapa do contraditório, cientificando a parte interessada sobre algum fato relevante. Em seguida a reação se corporifica pela adoção de uma postura da parte diante da informação, elegendo os meios aptos a serem adotados na defesa de seu interesse. As duas primeiras etapas do contraditório funcionam verdadeiramente como a terceira lei de Newton (Ação e reação).O diálogo é o efetivo exercício do contraditório, com o qual a parte se manifesta sobre fato relevante, cooperando assim pelo regular trâmite processual e postulando pelo seu interesse. Por fim, há a influência, caracterizada pelo resultado psíquico obtido na mente do julgador, na formulação da decisão judicial e na construção do provimento jurisdicional.

No processo penal cabe à acusação a carga probatória, imputando ao réu o cometimento de uma infração penal e pleiteando pela sua consequente condenação. Provocado pelo acusador, o acusado pode tomar duas posturas: Exercer seu direito constitucional ao silêncio estampado 
no artigo $5^{\circ}$, LXIII da CRFB (BRASIL, 1988) e a não produzir prova contra si mesmo (nemu tenetur se detegere), ou exercer o contraditório e aproveitar eventuais chances probatórias e alegar o que lhe interessar. Daí vem a ideia de processo como situação jurídica (GOLDSCHMIDT, 1925) em que o réu pode ou não aproveitar suas chances processuais, almejando uma sentença favorável, contudo, há o risco de uma sentença desfavorável (imprevisível, a priori), a depender de suas estratégias.

Por sua vez, a ampla defesa é prevista no Artigo $5^{\circ}$, LV da CRFB (BRASIL, 1988), no artigo 8 $8^{\circ}$ 2. "c" e "d" da Convenção Americana de Direitos Humanos e artigo 14. 3, "d" do Pacto Internacional sobre Direitos Civis e Políticos, se decompondo em um binômio, a defesa técnica e a defesa pessoal. O primeiro é aquele exercido por um profissional técnico habilitado na defesa dos interesses do acusado, considerada irrenunciável. Há uma presunção de hipossuficiência do acusado frente ao acusador, vez que na maioria das vezes o imputado não possui conhecimento adequado para entender a seriedade e as particularidades da acusação que é feita em seu desfavor, não podendo, assim, exercer, de forma eficiente, o contraditório e sua defesa.

A defesa técnica é uma exigência civilizatória, pois se está lidando com a liberdade das pessoas, cabendo ao Estado observar a plena defesa dos seus governados e refutar uma defesa simbólica, uma mera encenação. O advogado é indispensável à administração da justiça, conforme dispõe o artigo 133 da CRFB (BRASIL, 1988), promovendo uma estratégia apropriada para a situação de seu patrocinado. No mesmo patamar se encontra o Defensor Público, de acordo com o artigo 134 da CRFB (BRASIL, 1988) que promoverá a defesa dos necessitados economicamente, buscando tutelar o princípio da igualdade e efetivar a dignidade da pessoa humana, assegurando aos necessitados assistência jurídica integral, na trilha do artigo $5^{\circ}$, LXXIV da CRFB (BRASIL, 1988).

O segundo binômio é a autodefesa, consubstanciada na garantia do acusado de se defender, juntamente à defesa técnica. Nada mais lógico que haver por parte do acusado, que efetivamente possui muito em jogo, interesse no deslinde processual e corroborar, na medida do possível, para que lhe seja proferida uma decisão favorável. É facultado ao acusado o direito de presença e de audiência, tornando esse consectário disponível, e não poderia ser diferente, pois ao réu não lhe é exigido condutas comissivas, pois a autodefesa também abarca o direito ao silêncio e o de não produzir prova contra si mesmo. Porém, a disponibilidade é estratégia defensiva, de opção do acusado assistido por seu defensor, logo, deve-se ter muita cautela quando se argumenta a inocorrência de cerceamento de defesa quando o acusado não participa de algum ato, por ser a autodefesa disponível. A garantia da autodefesa é dirigida ao acusado e não ao Estado, não podendo transigir e dispor de direito cuja titularidade não é sua.

ROSMAR RODRIGUES ALENCAR, sobre a importância da dialeticidade procedimental, assevera que:

O diálogo processual, além de migrar do fundamento que o réu fala por último, deve possibilitar o contraditório, com confronto, paralelismo e obliquidade de argumentos. A paridade de armas (possibilidade dinâmica - ações equivalentes às deferidas ao órgão da acusação) deve ir além da isonomia (possibilidade estática - outorga de prazos idênticos aos sujeitos processuais). (ALENCAR, 2021, p. 714)

Tratadas muitas vezes como sinônimos, o contraditório e a ampla defesa são indissociáveis, mas não se confundem. Só há defesa se há informação e só há contraditório por meio da defesa. Leciona RONALDO BRÊTAS DE CARVALHO DIAS:

Já sustentamos anteriormente que o devido processo legal, principal alicerce do processo constitucional ou modelo constitucional do processo, considerado este a principiologia metodológica constitucional de garantia dos direitos fundamentais, 
deve ser entendido como um bloco aglutinante e compacto de vários direitos e garantias inafastáveis, ostentados pelas pessoas do povo (partes), quando deduzem pretensão à tutela jurídica nos processos, perante os órgãos jurisdicionais: a) direito de amplo acesso à jurisdição, prestada dentro de um tempo útil ou lapso temporal razoável; b) garantia do juízo natural; c) garantia do contraditório; d) garantia da ampla defesa, com todos os meios e recursos a ela (defesa) inerentes, aí incluído o direito à presença de advogado ou de defensor público; e) garantia da fundamentação racional das decisões jurisdicionais, com base no ordenamento jurídico vigente (reserva legal); f) garantia de um processo sem dilações indevidas. (BRÊTAS, 2018, p. 173)

Logo, verifica-se que contraditório e ampla defesa compõe o devido processo legal, de sorte que qualquer ofensa a tais postulados implica em violação a direito constitucional, e prestação jurisdicional deficiente.

Outro princípio de suma importância na análise da emendatio libelli é o da correlação ou congruência. Tal princípio busca uniformizar a dinâmica da acusação, defesa e sentença, preservando o contraditório e a ampla defesa. Assevera PAULO QUEIROZ:

O assim chamado princípio da congruência ou correlação entre acusação, defesa e sentença é uma dimensão essencial do princípio do contraditório e da ampla defesa e da inércia da jurisdição (ne procedat iudex ex officio), inerentes ao sistema de tipo acusatório-garantista. (QUEIROZ, 2020, p. 407)

Da mesma forma que a jurisdição é inerte, não podendo instaurar demandas sem a devida provocação das partes, o provimento jurisdicional não pode superar os limites do pedido e da causa de pedir, no processo civil, e a pretensão acusatória, no processo penal. Novamente nos valendo do magistério de RONALDO BRÊTAS, que, citando o conceito de decisão jurisdicional apresentado por ROSEMIRO PEREIRA LEAL, dispõe que a decisão jurisdicional é julgamento vinculado ao espaço-técnico-procedimental-discursivo do processo cognitivo de direitos, como conclusão coextensiva da argumentação das partes. (BRÊTAS, 2018, p. 186).

Nesse sentido, são vedadas as sentenças ultra, citra ou extra petita, pois ao decidir além, aquém ou diversamente do que pleiteado, o Magistrado foge das questões debatidas no processo, decidindo algo que não fora submetido ao contraditório e a ampla defesa, violando o devido processo legal e oferecendo uma prestação jurisdicional nula. Na esteira de PEDRO ARAGONESES ALONSO, citado por AURY LOPES JR., por congruência, deve entender-se aquele princípio normativo dirigido a delimitar as faculdades resolutórias do órgão jurisdicional, pelo qual deve existir identidade entre a decisão e o debatido, oportunamente, pelas partes. (ARAGONESES ALONSO, 1957, p. 87 apud LOPES JR., 2021, p. 983).

Pode-se afirmar que os princípios acima elencados são indispensáveis à correta compreensão e aplicação do instituto previsto no artigo 383 do Código de Processo Penal, na medida que, sempre, deve-se buscar a prestação jurisdicional em conformidade com a Carta Política. A seguida será discorrido sobre a aplicação da emendatio libelli propriamente dita, valendo-se das considerações já feitas para uma melhor exposição e assimilação.

\section{SENTENÇA E A EMENDATIO LIBELLI}

Ao nos recordar que a pretensão acusatória é o objeto do processo penal, temos noção da absoluta cautela a ser adotada em alterações da acusação ofertada. Isto porque o réu (presumido inocente por imposição constitucional), tem sua atuação condicionada àquilo que foi alegado pelo órgão acusador. Portanto, questões que não são apontadas pela acusação e assim, não rebatidas pela defesa (ao menos que lhe seja oportunizada tal medida), carecem de 
legitimidade para serem decididas pelo juízo, pois não se submeteram aos requisitos de validade na formação de um título executivo judicial.

O artigo 383 do Código de Processo Penal, dissociando as questões fáticas das questões jurídicas, permite ao Magistrado sentenciar diversamente do que foi pleiteado pela acusação, desde que a narrativa fática se mantenha incólume. Tal permissivo deriva do que anteriormente alegado sobre os brocardos "O juízo conhece o direito" e "Dá-me os fatos que lhe darei o direito", que necessitam de um aprofundamento crítico. Porém, questiona-se: É possível a atribuição jurídica diversa, mantendo-se a narrativa fática, sem prejuízo ao acusado? Entendo que não, uma vez que não há que se falar em dissociar questões fáticas de questões jurídicas, vez que umbilicalmente interligadas. Valendo-nos das lições de CASTANHEIRA NEVES, citado na obra de PAULO QUEIROZ:

Ou numa formulação bem mais expressiva: "para dizer-se a verdade "o puro facto" e o "puro direito" não se encontram nunca na vida jurídica: o facto não tem existência senão a partir do momento em que torna-se matéria de aplicação do direito, o direito não tem interesse senão no momento em que se trata de aplicar o facto; pelo que, quando um jurista pensa o facto, pensa-o como matéria do direito, quando pensa o direito, pensa-o como forma destinada ao facto (NEVES, 1967, p. 55/56 apud QUEIROZ, 2020, p. 128)

Ao se comparar a mutatio libelli e emendatio libelli, temos que a primeira prevê a cientificação do acusador da prova nova ou da circunstância da infração penal não contida na acusação, com a posterior manifestação da defesa, e, caso admitido o aditamento, verifica-se a determinação de audiência em continuação para que haja instrução compatível com a alteração. Tal procedimento respeita o contraditório, vez que ambas as partes se manifestaram acerca da questão, permitindo uma instrução adequada à nova circunstância, oportunizando a defesa quanto a esta.

Defende-se que mesmo na emendatio seja garantida às partes a oportunidade de se manifestar acerca da alteração, influindo no convencimento do juízo e na formação da sentença. Discorrendo acerca do permissivo contido no artigo, e suas complicações, RICARDO JACOBSEN GLOECKNER assevera que o artigo 383 consiste num dispositivo de flexibilização da imputação. Igualmente, cuida-se de tipo processual que cria ou estrutura uma situação jurídica potestativa, pois a sorte do acusado dependerá exclusivamente de uma deliberação do magistrado, inclusive, na ausência de contraditório. (GLOECKNER, 2016).

A figura da emendatio deve ser obrigatoriamente repensada à luz do sistema acusatório, privilegiando a interferência das partes, a uma, pois o Código de Processo Civil, aplicado analogicamente ao processo penal, veda as chamadas decisões surpresas (Artigo $9^{\circ}$ e 10), determinando ao Magistrado que as partes se manifestem, mesmo em casos que lhe seja permitido a atuação de ofício. A duas, pois apesar de o réu se defender, a princípio, de fatos e não de números ou artigos de lei, evidente que a qualificação jurídica é de suma relevância ao influir na espécie de procedimento (sumaríssimo, sumário ou ordinário), institutos penais e processuais (competência, prescrição, prisões cautelares, suspensão condicional do processo, dentre outros), além de ser capaz de ferir de morte a estratégia defensiva. Cristalino exemplo é dado por PAULO QUEIROZ:

Imagine-se, por exemplo, que, denunciado por furto simples (CP, art. 155, caput), o réu defende três teses: princípio da insignificância, uma das causas especiais de isenção de pena do art. 181 do CP (crime contra cônjuge, etc.) e prescrição, mas o juiz, surpreendentemente, condene por roubo simples (CP, art. 157, caput), delito que não admite tais alegações e cuja prescrição é o dobro do prazo (16 anos). Ora, é evidente que, além de surpreender as partes, a sentença violou o contraditório e a ampla defesa. Afinal, não houve contraditório algum, relativamente à inovação 
admitida na sentença. Nada mudaria substancialmente se, com a nova definição jurídico-penal, incidisse crime menos grave, já que a surpresa persistiria. (QUEIROZ, 2020, p. 129)

Logo, verifica-se que a crítica abarca, também, a condenação por crime menos grave, ou mesmo alteração do elemento subjetivo do crime (doloso para culposo) ou mesmo de autor para partícipe. A alteração pode ser (aparentemente) benéfica ao acusado, por vez que alguns podem defender que se trata também de aplicação da emendatio libelli, entretanto, cabe a mesma crítica, o acusado se defende nos limites do que lhe é imputado, e, caso seja condenado por delito culposo (invés de doloso, como na acusação), inexistente qualquer manifestação defensiva em tal hipótese, fulminando a estratégia defensiva adotada durante toda a instrução. Nesse trilhar, é válida a exposição de decisão proferida no REsp 1.388.440-ES, Rel. Nefi Cordeiro, j. 05/03/2015, Dje 17/03/2015, acerca da desclassificação de delito doloso para culposo:

Quando na denúncia não houver descrição sequer implícita de circunstância elementar da modalidade culposa do tipo penal, o magistrado, ao proferir a sentença, não pode desclassificar a conduta dolosa do agente - assim descrita na denúncia - para a forma culposa do crime, sem a observância do regramento previsto no art. 384, caput, do CPP. Com efeito, o dolo direto é a vontade livre e consciente de realizar a conduta descrita no tipo penal. A culpa, por sua vez, decorre da violação ao dever objetivo de cuidado, causadora de perigo concreto ao bem jurídico tutelado. A par disso, frise-se que, segundo a doutrina, " no momento de se determinar se a conduta do autor se ajusta ao tipo de injusto culposo é necessário indagar, sob a perspectiva ex ante, se no momento da ação ou da omissão era possível, para qualquer pessoa no lugar do autor, identificar o risco proibido e ajustar a conduta ao cuidado devido (cognoscibilidade ou conhecimento do risco proibido e previsibilidade da produção do resultado típico)". Nesse passo, a prova a ser produzida pela defesa, no decorrer da instrução criminal, para comprovar a ausência do elemento subjetivo do injusto culposo ou doloso, é diversa. Assim, não descrevendo a denúncia sequer implicitamente o tipo culposo, a desclassificação da conduta dolosa para a culposa, ainda que represente aparente benefício à defesa, em razão de imposição de pena mais branda, deve observar a regra inserta no art. 384, caput, do CPP. Isso porque, após o advento da Lei 11.719/2008, qualquer alteração do conteúdo da acusação depende da participação ativa do Ministério Público, não mais se limitando a situações de imposição de pena mais grave, como previa a redação original do dispositivo. Portanto, o fato imputado ao réu na inicial acusatória, em especial a forma de cometimento do delito, da qual se infere o elemento subjetivo, deve guardar correspondência com aquele reconhecido na sentença, a teor do princípio da correlação entre acusação e sentença, corolário dos princípios do contraditório, da ampla defesa e acusatório. REsp 1.388.440-ES, Rel. Min. Nefi Cordeiro, julgado em 5/3/2015, DJe 17/3/2015. (sem grifo no original)

\section{Argumenta AURY LOPES JR.:}

É elementar que o réu se defende do fato e, ao mesmo tempo, incumbe ao defensor, também, debruçar-se sobre os limites semânticos do tipo, possíveis causas de exclusão da tipicidade, ilicitude, culpabilidade, e em toda imensa complexidade que envolve a teoria do injusto penal. É óbvio que a defesa trabalha - com maior ou menor intensidade, dependendo do delito - nos limites da imputação penal, considerando a tipificação como pedra angular em que irá desenvolver suas teses. (LOPES JR., 2021, p. 1.206)

A permissão que o artigo 383 dá ao juízo, de alterar a qualificação jurídica do fato, não significa que pode o fazer diretamente, sem provocar a prévia comunicação e debate das partes, 
vez que os princípios do iura novit curia e narra mihi factum, dabo tibi ius não se sobrepõe aos princípios do contraditório e da ampla defesa, de estatura constitucional, elencados no artigo $5^{\circ}$, LV da CRFB (BRASIL, 1988). Quanto à prévia interferência das partes, GUSTAVO BADARÓ enfatiza que não há previsão legal em nosso ordenamento nesse sentido, mas o princípio do contraditório assim o exige (BADARÓ, apud LOPES JR., 2021, p. 989). No mesmo sentido, opondo-se à posição majoritária quanto ao instituto, RENATO BRASILEIRO DE LIMA pontua que

\footnotetext{
Em que pese essa ser a posição majoritária, pensamos que, em fiel observância ao contraditório, há necessidade de manifestação das partes na hipótese de possível alteração da capitulação atribuída ao fato delituoso. Se é verdade que o princípio iura novit curia confere ao juiz a possibilidade de alterar a classificação dos fatos constantes na peça acusatória, também não é menos verdade que o princípio do contraditório lhe impõe a comunicação prévia às partes, antes de tomar uma decisão, ainda que se trate daquelas que podem ser tomadas de ofício, evitando-se, assim, que as partes sejam indevidamente surpreendidas no momento da sentença com uma nova capitulação. (LIMA, 2020, p. 1.663)
}

Portanto, o que se busca demonstrar é que a figura da emendatio é problemática e possibilita decisões judiciais inválidas, ao permitir um juízo solipsista e solitário, totalmente desconectado de um processo caracterizado por partes, debate, oportunidades e garantias plenas na prestação jurisdicional. Parece absolutamente adequado que se exija a manifestação prévia das partes em hipóteses de emendatio, para evitar decisões surpresas e menosprezo ao devido processo constitucional.

\section{CONCLUSÃO}

O código de processo penal mistura dispositivos datados de sua promulgação, concebidos em aspirações autoritárias do código de processo penal italiano (Codice Rocco), com dispositivos garantistas e progressistas, levando a inegáveis inconsistências. Assim, no âmbito penal, a importância de que haja um controle de constitucionalidade (e por que não de convencionalidade) difuso é inegável. Não se pode permitir a aplicação dos dispositivos processuais penais sem a observância dos postulados constitucionais, que devem sempre se ver atendidos, como o são o contraditório e a ampla defesa, maculados pelo artigo 383 do Código de Processo Penal.

A problemática gira em volta da (aparente) desnecessidade de se comunicar às partes a respeito da eventual capitulação jurídica diversa daquela apresentada na acusação, que pautou as estratégias e posturas de autor e réu durante todo o iter procedimental. Trata-se de artigo que carrega consigo uma mentalidade inquisitória, em que o julgador ostentava de ampla discricionariedade na tomada de decisões no processo, esquecendo-se que a sentença penal é a materialização da prestação jurisdicional e da inafastabilidade da jurisdição, precedida do embate de teses daqueles que são verdadeiros interessados na jurisdição a ser prestada.

$\mathrm{O}$ acusador ingressa em juízo para fazer valer a lei penal frente a uma conduta que lesiona, ou, ao menos, expõe o bem jurídico a uma situação de perigo, e, em contrapartida, o acusado é demandado em juízo, pairando sobre eles graves consequências ao seu status libertatis, devendo lhe ser assegurado o devido processo legal. E o juízo sentenciante, o que lhe interessa na sentença? Ao juízo natural e imparcial, assegurados no Artigo 5, LIII e XXXVII da CRFB (BRASIL, 1988), seu interesse deve cingir-se na prestação da tutela jurisdicional útil, em tempo razoável e em conformidade com a lei (infraconstitucional e, principalmente, constitucional). 
Portanto, ao atribuir definição jurídica diversa ao caso penal debatido em juízo (sem oportunizar o contraditório), nem autor, réu ou julgador vêem satisfeitas suas pretensões, pois autor postulou de forma diversa, seguido pela defesa do acusado, também diversa do que decidido, e, ao Magistrado, que, em tese, apenas foi provocado para fazer valer o poder estatal de dizer o direito, frente ao caso concreto, tomou postura solipsista e individual para decidir conforme sua vontade, mediante sentença nula por violação aos preceitos constitucionais do Artigo $5^{\circ}$, LIV e LV da CRFB (BRASIL, 1988). Logo, oportunizar a manifestação das partes, antes do pronunciamento jurisdicional, é condição indispensável para a validade e legitimidade do ato, respaldado por disposição constitucional, que não pode sofrer mitigações por dispositivo infraconstitucional.O que se pretendeu defender no presente trabalho foi uma releitura constitucional do dispositivo criticado, para que dê a devida importância ao devido processo legal, e que o princípio da congruência ou correlação, não se limite ao binômio acusaçãosentença, e sim ao trinômio acusação-defesa-sentença.

\section{REFERÊNCIAS}

ALENCAR, Rosmar Rodrigues. Curso de Direito Processual Penal: Em conformidade com a teoria do direito. 1. ed. São Paulo: Noeses, 2021

BRASIL. Decreto-lei n⿳3.869, de 3 de outubro de 1941. Código de Processo Penal. Brasília, DF: Presidência da República, 2019. Disponível em: http://www.planalto.gov.br/ccivil_03/decreto-lei/del3689compilado.htm. Acesso em: 04 de out. 2021.

BRASIL. Decreto no 592, de 06 de julho de 1992. Atos Internacionais. Pacto Internacional sobre Direitos Civis e Políticos. Promulgação. Disponível em: http://www.planalto.gov.br/ccivil_03/decreto/1990-1994/d0592.htm. Acesso em: 02 fev. 2022.

BRASIL. Decreto no 678, de 06 de novembro de 1992. Promulga a Convenção Americana sobre Direitos Humanos (Pacto de San José da Costa Rica), de 22 de novembro de 1969. Disponível em: http://www.planalto.gov.br/ccivil_03/decreto/d0678.htm. Acesso em: 02 fev. 2022

BRASIL. Constituição da República do Brasil. Brasília, DF: Presidência da República, 2019. Disponível em: http://www.planalto.gov.br/ccivil_03/constituicao/constituicao.htm. Acesso em: 04 de out. 2021.

BRASIL. Lei no 13.964, de 24 de dezembro de 2019. Aperfeiçoa a legislação penal e processual penal. Brasília, DF: Presidência da República, 2019. Disponível em: http://www.planalto.gov.br/ccivil_03/_ato2019-2022/2019/lei/L13964.htm. Acesso em: 11 out. 2021

DIAS, Ronaldo Brêtas de Carvalho. Processo constitucional e Estado Democrático de Direito. 4. ed. Belo Horizonte: Del Rey, 2018.

DINAMARCO, Cândido Rangel; LOPES, Bruno Vasconcelos Carrilho; BADARÓ, Gustavo Henrique Righi Ivahy. Teoria Geral do Processo. 32. ed. São Paulo: Malheiros, 2020 
GLOECKNER, Ricardo Jacobsen. Três teses sobre a inconstitucionalidade substancial do art. 383 do CPP: por que o réu não se defende (apenas) dos fatos. Revista Brasileira de Direito Processual Penal, Porto Alegre, vol. 2, n. 1, p. 185 - 212, 2016.

http://dx.doi.org/10.22197/rbdpp.v2i1.21

LIMA, Renato, Brasileiro de. Manual de Processo Penal: Volume único. 8. ed. Salvador: JusPodivm, 2020.

LOPES JR., Aury. Direito Processual Penal. 18. ed. São Paulo: Saraiva Educação, 2021.

QUEIROZ, Paulo. Direito Processual Penal: Introdução. 2. ed. Salvador: JusPodivm, 2020. 